MALLOMO: Journal of Community Service

https://jurnal.umsrappang.ac.id/mallomo/index

Vol 1, No 2, Juni 2021, pp 73-79

\title{
Pelatihan Budidaya Maggot sebagai Alternatif Pakan Ikan Desa Carawali
}

\author{
Muhammad Bibin ${ }^{1}$, Ani Ardian², Adiba Nuwaira Mecca ${ }^{3}$ \\ ${ }^{1}$ Fakultas Sains dan Teknologi, Universitas Muhammadiyah Sidenreng Rappang \\ Email: muhbibin@umsrappang.ac.id \\ 2, 3 Universitas Muhammadiyah Sidenreng Rappang
}

Abstract. Commercial feed produced by the factory has a guaranteed quality and quantity. However, the problem is the price of commercial feed produced by factories that are getting more and more expensive and troubling to fish breeders, thus making fish breeders have to look for other alternatives to reduce the cost of feed. Cultivation of maggots or larvae of black soldier fly flies (Hermetia illicens) the right solution to overcome the problem in lieu of high-protein fish feed. Maggot cultivation training activities as an alternative to fish feed are carried out in Carawali Village. The implementation method is done by means of lectures, discussions and practices. The result of this community service activity is the amount of enthusiasm of participants to the training activities by evidenced that the active participants follow the activity from start to finish. In addition, many participants are active in discussion and question and answer sessions. So it can be concluded that the maggot cultivation training in Carawali Village went successfully and smoothly. The continuation of this PKM activity is to train the understanding and attitude of the trainees on the importance of organic waste management for maggot cultivation as an alternative to fish feed.

Abstrak. Pakan komersil yang diproduksi oleh pabrik memiliki kualitas dan jumlah yang terjamin. Akan tetapi permasalahannya adalah harga pakan komersil yang diproduksi oleh pabrik yang semakin hari semakin mahal dan meresahkan para pelaku pembudidaya ikan, sehingga membuat para pelaku pembudidaya ikan harus mencari alternatif lain untuk menekan biaya pakan. Budidaya maggot 
Keywords:

Maggot; Black

Soldier Fly; Fish

Feed Alternative.

Kata Kunci:

Maggot, Black

Soldier Fly, Alternatif Pakan

Ikan. atau larva lalat black soldier fly (Hermetia illicens) solusi yang tepat untuk mengatasi permasalahan tersebut sebagai pengganti pakan ikan yang berprotein tinggi. Kegiatan pelatihan budidaya maggot sebagai alternatif pakan ikan dilaksanakan di Desa Carawali. Metode pelaksanaan dilakukan dengan cara ceramah, diskusi dan praktek. Hasil dari kegiatan pengabdian kepada masyarakat ini adalah besarnya antusias peserta terhadap kegiatan pelatihan dengan dibuktikan bahwa aktifnya peserta mengikuti kegiatan dari awal sampai akhir. Selain itu, banyak peserta yang aktif dalam sesi diskusi dan tanya jawab. Sehingga dapat disimpulkan bahwa pelatihan budidaya maggot di Desa Carawali berjalan dengan sukses dan lancar. Kelanjutan dari kegiatan PKM ini adalah melatih pemahaman dan sikap peserta pelatihan tentang pentingnya pengelolaan limbah organik untuk budidaya maggot sebagai alternatif pakan ikan.

Coresponden author: Email: $\underline{\text { muhbibin@umsrappang.ac.id }}$ (c) (i) artikel dengan akses terbuka di bawah lisensi CC BY -4.0

\section{PENDAHULUAN}

Pakan merupakan salah satu faktor yang penting dalam menunjang suatu perkembangan usaha budidaya ikan. Ketersediaan pakan akan berpengaruh terhadap pertumbuhan dan kelangsungan hidup ikan yang dibudidayakan (Zaenuri, 2013). Pakan dibagi menjadi dua yaitu pakan alami (natural food) dan pakan buatan (artificial food). Pakan alami merupakan pakan yang tersedia di alam seperti plankton (Pratiwi et al., 2011). Sedangkan pakan buatan yaitu pakan yang dibuat dengan formula tertentu, sesuai dengan kebutuhan biota kultur agar dapat memenuhi kebutuhan nutrisi (Arief, Triasih, et al., 2019).

Usaha budidaya perikanan memerlukan pakan yang cukup untuk pertumbuhan ikan. Pemanfaatan bahan pakan hingga saat ini belum tertanggulangi, dalam arti kompotensi antara pangan dan pakan masih terus berlanjut terutama pakan sebagai sumber protein, sehingga menimbulkan dilema bagi pembudidaya (Amin et al., 2020). Usaha budidaya perikanan secara intensif memerlukan pakan komersil yang tepat mutu dan tepat jumlah. Pakan merupakan salah satu faktor yang penting dalam menunjang suatu perkembangan usaha budidaya ikan (Dani et al., 2005). Ketersediaan pakan akan berpengaruh terhadap pertumbuhan dan kelangsungan hidup ikan yang dibudidayakan. Pakan komersil yang diproduksi oleh pabrik memiliki kualitas dan jumlah yang terjamin. Akan tetapi permasalahannya adalah harga pakan komersil yang diproduksi oleh pabrik yang semakin hari semakin 
mahal dan meresahkan para pelaku pembudidaya ikan. Hal ini akan menyebabkan naiknya biaya produksi. Kenaikan biaya produksi akan berpengaruh terhadap harga-harga produk perikanan. Secara tidak langsung, konsumenlah yang dibebankan untuk menanggung pembengkakan biaya produksi tersebut. Pada akhirnya daya beli konsumen menjadi penentu akhir keberlanjutan industri budidaya perikanan. Apabila daya beli konsumen rendah maka dapat menimbulkan masalah.

Maggot atau larva lalat black soldier fly (Hermetia illicens) merupakan organisme pembusuk karena kebiasaannya mengkonsumsi bahan-bahan organik. Maggot merupakan alternatif pakan yang memenuhi persyaratan sebagai sumber protein (Fauzi \& Sari, 2018). Menurut (Amelia, 2014) dan (Raharjo et al., 2016) maggot mengandung protein 39.95\%, maggot black soldier fly juga mengandung anti mikroba dan anti jamur, sehingga tidak membawa penyakit pada ikan. Syarat bahan yang dapat dijadikan bahan baku pakan seperti tidak berbahaya bagi ikan, tersedia sepanjang waktu, mengandung nutrisi sesuai dengan kebutuhan ikan, dan bahan tersebut tidak berkompetisi dengan kebutuhan manusia (Minggawati et al., 2019). Ada beberapa pembudidaya mencoba untuk mengkultur pakan alami yakni maggot dengan bungkil kelapa sawit atau dengan dedak padi. Berdasarkan hasil proksimat maggot yang telah dilakukan, (Setiawibowo et al., 2009) menyebutkan bahwa maggot yang dikultur dengan menggunakan bungkil kelapa sawit terfermentasi memiliki kandungan protein $38.82 \%$. Sedangkan menurut (Indariyanti \& Barades, 2018) dan (Azir et al., 2017) maggot yang dikultur dengan menggunakan dedak padi memiliki kandungan protein $37.97 \%$.

Penggunaan maggot atau larva lalat black soldier fly (Hermetia illicens) sebagai pakan sangat mudah diterapkan, tidak sama halnya pabrik pakan yang menggunakan formulasi pakan yang cukup rumit dan menggunakan biaya yang cukup mahal (Madusari et al., 2019). Maggot dapat dijadikan pakan secara langsung dalam bentuk segar ataupun dicampur bahan lain seperti dedak padi dan bungkil kelapa sawit untuk dijadikan pelet (Arief, Ratika, et al., 2019); (Bokau \& Basuki, 2018). Hal ini tentunya akan memudahkan para pembudidaya ikan untuk memproduksi pakan secara mandiri sehingga otomatis biaya produksi dapat ditekan tanpa mengurangi pertumbuhan ikan. Dengan melihat kondisi tersebut maka dapat dimungkinkan untuk membuat pakan murah yang berasal dari bahanbahan limbah. Tujuan dilaksanakan kegiatan pengabdian kepada masyarakat (PKM) ini adalah memberikan solusi untuk memecahkan masalah dalam bidang budidaya perikanan yang terkendala akibat terus meningkatnya harga pakan yang sangat memberatkan terutama bagi petani pembudidaya ikan dengan modal kecil. Adapun manfaat dari kegiatan pengabdian kepada masyarakat (PKM) ini adalah diharapkan menjadi refensi/acuan untuk memproduksi pakan ikan secara sederhana dan murah.

\section{Metode}

Sasaran kegiatan Pengabdian Kepada Masyarakat ini adalah warga Desa Carawali Kecamatan Wattang Pulu Kabupaten Sidenreng Rappang. Kegiatan PKM ini juga melibatkan mahasiswa IImu Perikanan Universitas Muhammadiyah Sidenreng Rappang dengan tujuan untuk meningkatkan pemahaman dan keterampilan mahasiswa dalam budidaya maggot sebagai alternatif pakan ikan. Kegiatan PKM dilaksanakan selama 1 (satu) bulan diawali dengan survei awal untuk mengumpulkan data rancangan detail kegiatan. Kegiatan PKM ini menggunakan pendekatan bersifat persuasif edukatif dengan menggunakan metode ceramah, diskusi, dan praktek, melalui tahapan sebagai berikut:

1. Tim PKM melakukan survei lokasi pada bulan Januari 2021.

2. Tim PKM untuk membuat perencanaan kegiatan yang mencakup waktu, materi dan teknis 
pelaksanaan kegiatan.

3. Koordinasi dengan pemerintah Desa Carawali sebagai tempat pelaksanaan kegiatan mengenai teknis pelaksanaan kegiatan, tempat, fasilitas dan peserta.

4. Setelah pemerintah Desa Carawali memberikan kepastian waktu dan tempat pelaksanaan, tim PKM dibantu oleh mahasiswa Ilmu Perikanan Universitas Muhammadiyah Sidenreng Rappang mengundang masyarakat untuk menjadi peserta pelatihan dengan target peserta yang telah ditetapkan sebanyak 40 orang.

5. Pelaksanaan pelatihan dibuka oleh Kepala Desa Carawali dan ketua tim PKM sekaligus ketua program studi Ilmu Perikanan Universitas Muhammadiyah Sidenreng Rappang.

6. Kegiatan pelatihan menggunakan metode ceramah untuk menumbuhkan motivasi peserta akan pentingnya budidaya maggot sebagai alternatif pembuatan pakan pada ikan. Metode ceramah juga digunakan untuk memberikan pengetahuan dan pemahaman mengenai konsep dasar dan teknik-teknik dalam budidaya maggot serta pemanfaatan sampah organik.

7. Selanjutnya dalam pelatihan ini dilakukan diskusi kepada peserta/masyarakat dengan tujuan melahirkan ide serta gagasan kreatifnya dengan melihat beragam potensi di Desa Carawali.

8. Melakukan praktek pembuatan kandang untuk tempat budidaya maggot dan sekaligus cara pembuatan maggot dari limbah organik.

9. Pendampingan kepada peserta/masyarakat berupa layanan konsultasi bila ditemui permasalahan mengenai proses budidaya maggot.

\section{Hasil Dan Pembahasan}

Program pengabdian kepada masyarakat (PKM) Desa Carawali melalui budidaya maggot sebagai alternatif pakan ikan dilakukan secara terstruktur dengan melibatkan masyarakat secara langsung. Kegiatan PKM ini dimulai dengan tim berkunjung ke Desa Carawali untuk bertemu dengan Kepala Desa dan masyarakat sekitar. Dalam pertemuan itu dihasilkan beberapa kesepakatan antara lain mengadakan kegiatan pelatihan budidaya maggot sebagai alternatif pakan pada ikan serta waktu dan tempat pelaksanaan pelatihan. Kegiatan pelatihan budidaya maggot ini dilakukan untuk membantu masyarakat pembudidaya ikan dalam pembuatan pakan ikan secara mandiri dengan berbahan baku maggot atau larva lalat black soldier fly (Hermetia Illicens). Kegiatan ini dilaksanakan pada tanggal 14 januari 2021 yang bertempat di Aula Balai Desa Carawali. Lokasi ini dipilih karena letaknya strategis dan mudah dijangkau oleh peserta pelatihan. Peserta pelatihan, sebanyak 40 orang yang hadir terdiri dari kelompok pembudidaya ikan, pemuda desa dan masyarakat Desa Carawali. Pelatihan ini juga melibatkan 12 orang mahasiswa program studi ilmu perikanan UM Sidenreng Rappang. Mahasiswa berperan sebagai fasilitator.

Materi pelatihan yang disampaikan menggunakan metode ceramah dengan alat bantu berupa powerpoint yang disajikan melalui LCD (Gambar 1). Pada pemaparan materi pertama pelatihan ini, diarahkan pada pengenalan dan pemahaman peserta mengenai lalat black soldier fly dan bagaimana memanfaatkan untuk menghasilkan larva maggot. Pelatihan ini juga menjelaskan kepada peserta mengenai manfaat maggot sebagai alternatif pakan pada ikan.

Materi kedua adalah tahapan-tahapan dalam budidaya maggot dimulai dari pemilihan limbahlimbah organik. Dilanjutkan dengan penyortiran sampah organik yang memiliki kandungan protein tinggi, karena untuk menghasilkan maggot yang berkualitas harus diperhatikan jenis sampah yang 
memiliki kadar protein yang baik. Setelah itu dilanjutkan dengan materi ketiga yaitu cara membuat kandang yang tepat untuk budidaya maggot dan teknik penempatan sampah dalam kandang sehingga bisa memancing lalat black soldier fly (BSF) untuk datang ke kendang dan pemaparan materi yang terakhir adalah penyortiran antara larva BSF dan non BSF.

Setelah pemaparan materi mengenai budidaya maggot selesai dilanjutkan dengan sesi diskusi dan tanya jawab, pada sesi ini masyarakat yang hadir sangat antusias dengan melontarkan berbagai pertanyaan. Banyak hal yang membuat peserta tertarik salah satunya adalah pemanfaatan limbah organik yang dapat menghasilkan keuntungan sebagai tambahan pemasukan keuangan keluarga khususnya dimasa pandemi Covid-19 ini.

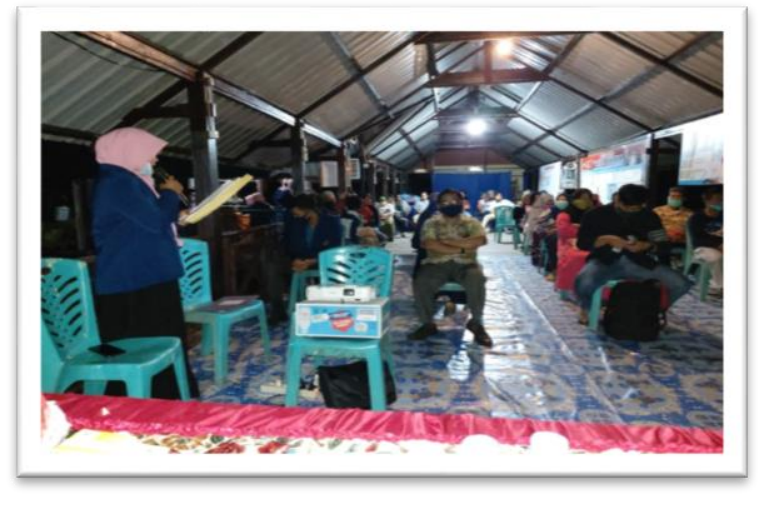

\section{Gambar 1. Pelaksanaan pelatihan budidaya maggot di Desa Carawali}

Sesi terakhir dari kegiatan PKM ini yaitu praktek. Dalam praktek kali ini kami tim PKM menggunakan sampah organik berupa sayuran dan buah-buahan yang sudah dicacah sebagai media tumbuh larva black soldier fly (BSF) serta membawa contoh larva black soldier fly (BSF). Tim juga membuat kandang untuk budidaya maggot dengan ukuran 150 × 75 x $90 \mathrm{~cm}$. Kandang maggot ini dilengkapi dengan kawat kasa, waring sebagai dinding dan menggunakan seng sebagai atap (Gambar 2a). Didalam kandang terdapat wadah maggot berserta media tumbuh maggot dari limbah organik. Selanjutnya tim PKM mempraktekkan cara penempatan limbah-limbah organik didalam kandang (Gambar 2b) serta memberikan contoh kepada peserta/masyarakat bagaimana cara membedakan larva black soldier fly (BSF) dan non larva black soldier fly (Gambar 2c) karena tidak menutup kemungkinan kandang yang berisi limbah organik juga akan didatangi oleh lalat non BSF seperti lalat rumah (Musca Domestica). 


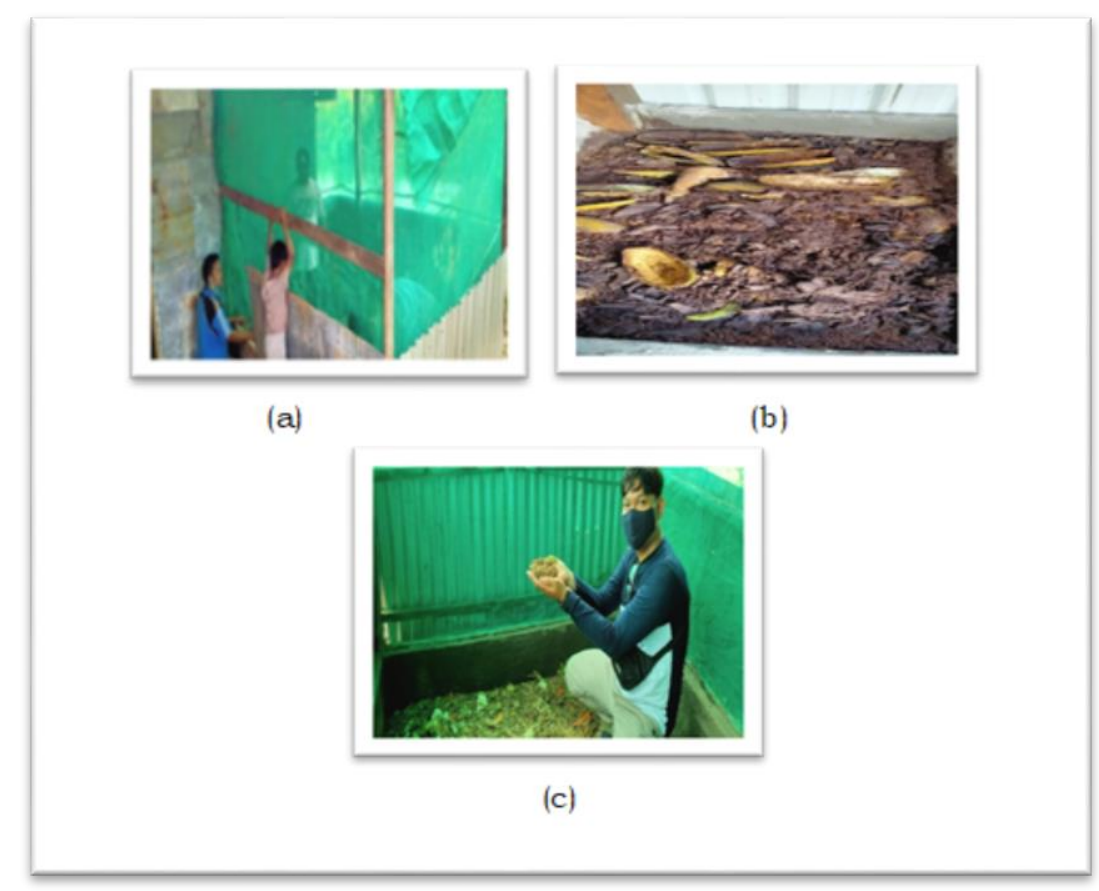

Gambar 2. (a) proses pembuatan kandang untuk budidaya maggot, (b) penempatan limbah organik didalam kandang (c) memberikan contoh cara membedakan larva black soldier fly (BSF) dan non larva black soldier fly (BSF).

\section{Simpulan Dan Saran}

Kesimpulan yang diperoleh dari pelaksanaan kegiatan pengabdian kepada masyarakat (PKM) ini adalah peserta sangat antusias terhadap kegiatan pelatihan budidaya maggot sebagai alternatif pakan ikan. Peserta pelatihan terdiri dari kelompok pembudidaya ikan, pemuda desa dan masyarakat Desa Carawali. Pelatihan tersebut memberikan manfaat bagi peserta/masyarakat, seperti meningkatnya pemahaman dan sikap peserta tentang pentingnya pengelolaan limbah untuk budidaya maggot serta meningkatnya keterampilan peserta terkait dengan pemanfaatan budidaya maggot sebagai alternatif pakan pada ikan.

Adapun rekomendasi dan masukan untuk kegiatan pengabdian masyarakat yang serupa di masa yang akan datang adalah pelatihan produksi massal larva manggot dan pembuatan pakan ikan buatan (pelet) berbasis bahan maggot, bungkil kelapa sawit, dan lemna minor.

\section{Daftar Rujukan}

Amelia, R. R. (2014). Study on the Effect of Fermentatiom and Liquid Waste Oil Cow on Protein Maggot (Hermetia Illucens). Fiseries, 3(1), 14-17.

Amin, M., Taqwa, F. H., Yulisman, Y., Mukti, R. C., Rarassari, M. A., \& Antika, R. M. (2020). Efektivitas Pemanfaatan Bahan Baku Lokal Sebagai Pakan Ikan Terhadap Peningkatan Produktivitas Budidaya Ikan Lele (Clarias sp.) di Desa Sakatiga, Kecamatan Indralaya, Kabupaten Ogan Ilir, Sumatera Selatan. Journal of Aquaculture and Fish Health, 9(3), 222. https://doi.org/10.20473/jafh.v9i3.17969

Arief, M., Ratika, A. N., \& Lamid, M. (2019). Pengaruh Kombinasi Media Bungkil Kelapa Sawit Dan Dedak Padi Yang Difermentasi Terhadap Produksi Maggot Black Soldier Fly (Hermetia illucens) Sebagai 
Sumber Protein Pakan Ikan. Jurnal Ilmiah Perikanan Dan Kelautan, 4(1), 33-37. https://doi.org/10.20473/jipk.v4i1.11580

Arief, M., Triasih, I., \& Lokapirnasari, W. P. (2019). Pengaruh Pemberian Pakan Alami Dan Pakan Buatan Terhadap Pertumbuhan Benih Ikan Betutu (Oxyeleotris marmorata bleeker). Jurnal IImiah Perikanan Dan Kelautan, 1(1), 51. https://doi.org/10.20473/jipk.v1i1.11698

Azir, A., Harris, H., \& Bayu, R. K. H. (2017). Production and Nutrition Maggot (Chrysomya Megacephala) Using Different Culture Media Composition. Jurnal IImu-IImu Perikanan Dan Budidaya Perairan, 12(1), 34-40.

Bokau, R. J. M., \& Basuki, T. P. (2018). Bungkil Inti Sawit sebagai Media Biokonversi Produksi Massal Larva Maggot dan Uji Respon Pemberian pada Ikan Nila (Oreochromis niloticus). Prosiding Seminar Nasional Pengembangan Teknologi Pertanian, 122-128. http://jurnal.polinela.ac.id/index.php/PROSIDING

Dani, N. P., Budiharjo, A., \& Listyawati, S. (2005). Komposisi Pakan Buatan untuk Meningkatkan Pertumbuhan dan Kandungan Protein Ikan Tawes (Puntius Javanicus Blkr.). BioSMART, 7(2), 8390.

Fauzi, R. U. A., \& Sari, E. R. N. (2018). Analisis Usaha Budidaya Maggot sebagai Alternatif Pakan Lele. Jurnal Teknologi Dan Manajemen Agroindustri, 7(1), 39-46. https://doi.org/https://doi.org/10.21776/ub.industria.2018.007.01.5

Indariyanti, N., \& Barades, E. (2018). Evaluasi Biomassa dan Kandungan Nutrisi Magot (Hermetia illucens) Pada Media Budidaya yang Berbeda. Prosiding Seminar Nasional Pengembangan Teknologi Pertanian, 137-141. https://jurnal.polinela.ac.id/index.php/PROSIDING/article/view/1151

Madusari, B. D., Sajuri, S., Wibowo, D. E., \& Irawati, M. (2019). Penggunaan Pakan Buatan Berbasis Maggot Dan Lemna Minor Pada Pokdakan Di Kota Pekalongan. Abdimas Unwahas, 4(1), 26-30. https://doi.org/10.31942/abd.v4i1.2691

Minggawati, I., Lukas, L., Youhandy, Y., Mantuh, Y., \& Augusta, T. S. (2019). PEMANFAATAN TUMBUHAN APU-APU (Pistia stratiotes) UNTUK MENUMBUHKAN MAGGOT (Hermetia illucens) SEBAGAI PAKAN IKAN. Ziraa'Ah Majalah Ilmiah Pertanian, 44(1), 77. https://doi.org/10.31602/zmip.v44i1.1665

Pratiwi, N. T. M., Winarlin, ., Frandy, Y. H. E., \& Iswantari, A. (2011). The potency of plankton as natural food for hard-lipped barb larvae (Osteochilus hasselti C.V.). Jurnal Akuakultur Indonesia, 10(1), 81. https://doi.org/10.19027/jai.10.81-88

Raharjo, E. I., Rachimi, \& Muhamad, A. (2016). Pengaruh Kombinasi Media Ampas Kelapa Sawit Dan Dedak Padi Terhadap Produksi Maggot (Hermetia illucens). Jurnal Ruaya : Jurnal Penelitian Dan Kajian IImu Perikanan Dan Kelautan, 4(2), 41-46. https://doi.org/10.29406/rya.v4i2.702

Setiawibowo, D. A., Sipayung, D. A., \& Putra, H. G. P. (2009). Pengaplikasian maggot sebagai alternatif pakan pada ikan.

Zaenuri, R. (2013). Kualitas Pakan Ikan Berbentuk Pelet dari Limbah Pertanian. Jurnal Sumberdaya Alam Dan Lingkungan, 31-36. 